\title{
Electrocardiographic and laboratory alterations in anorexic cats
}

\section{Alterações eletrocardiográficas e laboratoriais em gatos anoréxicos}

\author{
Jessica Junckes ${ }^{1}$; Eduarda Aléxia Nunes Louzada Dias Cavalcanti²; Roberta \\ Oliveira de Carvalho ${ }^{1}$; Thames Camargo Ignácio ${ }^{1}$; Maristela Silveira Palhares ${ }^{3}$; \\ Guilherme Albuquerque de Oliveira Cavalcanti ${ }^{4 *}$
}

\section{Highlights:}

The characterization of anorexia is very important in the feline specie.

Laboratory tests showed active muscle damage.

The electrocardiographic examination detected changes in heart rate and waveforms.

The electrocardiogram can identify anorexic cats.

\begin{abstract}
Anorexia, the result of inadequate nutrient intake, can lead to death and is a constant problem in the feline clinic. However, we did not find any previous studies that evaluated cardiac measures in felines. Therefore, we evaluated 27 emaciated cats by means of hematological exams, urinalysis, and electrocardiography. In the serum, we noted increased creatine kinase, aspartate aminotransferase, and lactate enzyme levels. Further, $62.96 \%$ of the cats exhibited electrocardiographic alterations. The most frequent electrocardiographic changes were increased QRS complex duration and QT interval increase. As clinicians become more aware of cardiovascular complications related to malnutrition, they are better able to recognize and assist this animal class.
\end{abstract}

Key words: Felines. Electrocardiogram. Starvation. Malnutrition.

\section{Resumo}

\begin{abstract}
A anorexia é resultante do consumo inadequado de nutrientes, pode levar ao óbito e é um problema constante na clínica de felinos. Porém não se encontram avaliações cardíacas na espécie felina. Portanto, avaliaram-se por meio de exames hematológicos, de urinálise e eletrocardiográficos 27 gatos emaciados. Observaram-se aumento nas enzimas séricas creatina quinase, aspartato aminotrasnferase e Lactato, além de alterações eletrocardiográficas em $62,96 \%$ dos gatos. As alterações eletrocardiográficas mais encontradas foram aumento na duração do complexo QRS e aumento no intervalo QT. Á medida que os clínicos se tornam mais conscientes das complicações cardiovasculares relacionados a desnutrição são mais capazes de reconhecer e auxilar melhor essa classe animal.
\end{abstract}

Palavras-chave: felinos. Eletrocardiograma. Inanição. Desnutrição.

\footnotetext{
1 Veterinárias Autônomas, Pelotas, Brasil. E-mail: jessicajunckes73@gmail.com; thamesscamargo@gmail.com; robertaoliv@ hotmail.com

2 Discente do Curso de Mestrado do Programa de Pós-Graduação em Veterinária, Universidade Federal de Pelotas, UFPEL, Pelotas, RS, Brasil. E-mail: nuneslouzadadias@gmail.com

3 Prof ${ }^{a}$ Dr $^{\mathrm{a}}$, Departamento de Clínica e Cirurgia Veterinárias da Universidade Federal de Minas Gerais, UFMG, Belo Horizonte, MG. Brasil. E-mail: maristelapalhares@gmail.com

4 Prof. Dr., Departamento de Clínicas Veterinária, UFPEL, Pelotas, RS. Brasil. E-mail: guialbuquerque@yahoo.com

* Author for correspondence
} 
Malnutrition is defined as the biological expression of the prolonged lack of nutrient intake. In animals, this condition is caused by inadequate or insufficient diet, malabsorption, or excessive loss of nutrients (Thatcher, Hand, \& Remillard, 2010). Malnutrition has anatomical and functional consequences, including anemia, reduction of muscle mass, impairment of mechanical respiratory function, and altered intestinal capacity. Hence, the identification of anorexic cats is necessary and essential in the prevention of feline hepatic lipidosis, a disease with devastating effects to this species (Upegui \& Gómez, 2015; Webb, 2018).

When they do not consume enough calories, sick or traumatized animals catabolize the protein from their lean mass, a phenomenon that causes metabolic imbalance. Since all protein in the body is functional, this catabolism compromises different systems, including the cardiac, respiratory and immune systems; this disruption can lead to death (Thatcher et al., 2010; Upegui \& Gómez, 2015; Webb, 2018). Humans with anorexia nervosa present laboratory and electrocardiographic abnormalities, as well as lower life expectancy, compared to the general population (Upegui \& Gómez, 2015).

Felines stop feeding when they are minimally sick, or even with no definite cause. They may lose much of their muscle mass and eventually die (Webb, 2018). Even in the face of this problem, we have found no electrocardiographic characterization of emaciated cats without concomitant disease in the literature.

We selected 27 mongrel cats (17 males and 10 females), with a body score between 1 and 2 (Laflamme, 1997), negative for FILV and FELV on SNAP combo FIV/Felv - IDEXX, among all the animals brought for consultation in a veterinary hospital. The mean body weight was $2.8 \mathrm{~kg}$ (range 1.6-3.9 kg). All cats had decreased appetite, and we performed complete clinical and cardiac examinations, urinalysis (performed by cystocentesis and evaluated with a reagent strip
(BioColor, Bioeasy®), hemogram, biochemical profile (determination of alanine aminotransferase [ALT] activity, aspartate transaminase [AST], alkaline phosphatase [ALP], creatine kinase [CK], quantification of total protein, albumin, cholesterol, triglycerides, glucose, calcium, phosphorus, urea, creatinine, lactate, and D-3-hydroxybutyrate), and electrocardiogram (ECG). All procedures were in accordance with the ethical standards of the Brazilian Committee on Animal Experimentation and approved in CEEA, under protocol $\mathrm{n}^{\circ}$ 4343/2017.

We performed the electrocardiogram (ECG 6 - ECAFIX FUNBEC ${ }^{\circledR}$, speed $50 \mathrm{~mm} / \mathrm{s}, 1 \mathrm{~cm}=$ $1 \mathrm{mV}$ ) on bipolar leads (I, II, and III) and unipolar leads (aVR, aVL, and aVF). We subsequently verified: heart rate; heart rhythm; duration of the QRS complex; duration of PR and QT intervals; the amplitudes $(\mathrm{mV})$ of the $\mathrm{R}$ and $\mathrm{T}$ waves; the relation of the height of the $\mathrm{T}$ wave with the height of the $\mathrm{R}$ wave; and the height and width of the $\mathrm{P}$ wave. We considered electrocardiographic tracings with alterations according to the parameters established by Tilley and Goodwin (2002). After obtaining all the data, we performed descriptive analysis with data from the specific literature for the species in question.

The urinary density measured on a refractometer varied from 1010 to 1040 , with a median of 1030 ; the urinary $\mathrm{pH}$ was $6.6 \pm 0.3$. The alterations observed in the urinalysis of malnourished felines were proteinuria in 14 samples $(60.8 \%)$, bacteriuria $(0.75 \pm 0.25)$ in 19 samples $(82.6 \%)$, presence of leukocytes $(0.166 \pm 0.17)$ in $8.4 \%$, presence of ammonia magnesium phosphate crystals $(0.31 \pm$ 0.29 ) in seven (30.4\%), and the existence of vesical cells $(+)$ in three samples $(13 \%)$.

Proteinuria may be of physiological or pathological origin. A physiological cause includes strenuous exercise, fever, and stress. On the other hand, a pathological origin may be related to bacteriuria or pyuria. We observed crystalluria in 
four samples (17.39\%); this phenomenon may have occurred due to reduced water intake or subclinical urinary infection in these animals (Kaneko, Harvey, \& Bruss, 2008). Although no animal in this study presented clinical signs of cystitis, it is known that anorexic humans have proteinuria and cystitis (Bagga et al., 2003; Bouquegneau, Dubois, Krzesinski, \& Delanaye, 2012).

The altered hematological results included urea (100mg dL $\mathrm{m}^{-1}$, reference value $20-30 \mathrm{mg} \mathrm{dL}^{-1}$ ), CK level $\left(280 \mathrm{U} \mathrm{L}^{-1}\right.$, reference value $\left.10-100 \mathrm{U} \mathrm{L}^{-1}\right)$, and-less consistently-increased AST $\left(47 \mathrm{U} \mathrm{L}^{-1}\right.$, reference value $\left.23-43 \mathrm{U} \mathrm{L}^{-1}\right)$ and lactate $(2.5 \mathrm{mmol}$ $\mathrm{L}^{-1}$, reference value 0.4-13.7 $\mathrm{mmol} \mathrm{L}^{-1}$ ) (Acierno, Johnsom, Eddleman, \& Mitchell, 2008). These enzymes increase in lesions of the muscular fibers (Kaneko et al., 2008) and thus indicate muscular catabolism in the cats of the current experiment. Webb (2018) correlated a serum urea increase with cachexia, as normal creatinine values indicate renal sanity.

High CK activity may occur in cardiac infarction and muscle damage, such as prolonged decubitus, muscle ischemia, seizures, tremors, trauma, excessive exercise, necrosis, surgeries, intramuscular injections, shock, and nutritional myopathies (Kaneko et al., 2008). In cats, it may serve as a marker of nutritional status, since it is elevated during anorexia, when muscle tissue is consumed to provide amino acids for gluconeogenesis (Fascetti, Mauldin, \& Mauldin, 1997).

Muscle injuries of various etiologies may be associated with increased lactate, for example myoglobinuria, vitamin E, and selenium deficiency, as well as myopathies: ischemia, bacterial endocarditis, heartworm, aortic thrombosis, and myocardial infarction (Kaneko et al., 2008). We hypothesize that lactate, CK and AST changes occurred due to the need of muscular consumption for energy production in the felines of the present experiment.

In humans affected by anorexia nervosa, in addition to the decrease in skeletal muscle mass, there is a decrease in the cardiac mass (Gottdiener, Howard, Henry, Borer, \& Ebert, 1978). The same phenomenon can occur in felines. Indeed, in addition to changes in muscle enzymes, we observed electrocardiographic changes in the obtained tracings.

Our electrocardiographic analysis showed 17 $(62.96 \%)$ traces with an alteration (Table 1), so the electrocardiographic changes in anorexic cats are as important as in humans, a species where the multidisciplinary approach is necessary to identify changes that indicate elevated risk for arrhythmias and sudden death (Upegui \& Gómez, 2015).

\section{Table 1}

Percentage (\%) and Absolute Number (N) of Electrocardiographic Alterations in Cats with Anorexia*

\begin{tabular}{ccc}
\hline Electrocardiographic alteration & $\%$ & $N$ \\
\hline Increased QRS duration & 33.33 & 9 \\
Increased QT interval & 25.92 & 7 \\
Increased T wave & 14.81 & 5 \\
Sinus arrhythmia & 7.40 & 2 \\
PVC $^{\#}$ & 7.40 & 2 \\
R wave amplitude increased & 7.40 & 2 \\
\hline
\end{tabular}

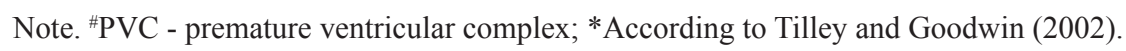


In the analysis of the rhythm, we found that the sinus rhythm was predominant in the evaluated animals. However, two of the animals $(7.40 \%)$ presented sinus arrhythmia. This condition is abnormal in cats (Tilley \& Goodwin, 2002), but anorexic cats have never been evaluated for this electrocardiographic alteration. In anorexic humans, generalized vagal cardiac hyperactivity has been demonstrated by means of cholinergic blockades, non-invasive vagal tonometer indices, and baroreflex sensitivity evaluation (Kollai, Bonyhay, Jokkel, \& Szonyi, 1994). Hence, we believe that the observed sinus arrhythmia is due to the influence of anorexia on the heart of these cats.

Vagal stimulation also increases heart rate variability and the QT interval (Kollai et al., 1994). However, it is difficult to define the exact cause of a prolonged QT interval in an ECG because it may occur in cases of hypokalemia, hypothermia, quinidine use, bradycardia, intoxication by ethylene glycol, strenuous activity, or SNC disorders (Tilley \& Goodwin, 2002). More than a quarter of the animals in this experiment exhibited an increased QT interval. A likely explanation for this prolongation might be because with little energy in the body, any physical activity becomes strenuous to the animal. Alternatively, vagal hyperexcitability might have contributed to this prolongation (Upegui \& Gómez, 2015).

Human patients with anorexia nervosa commonly show prolongation in the QT interval of the electrocardiographic tract (Upegui \& Gómez, 2015), which normalizes after oral potassium supplementation (Franzoni, Mataloni, Femia, \& Galetta, 2002). The QT interval indicates the quality of ventricular repolarization. Increases in its duration or dispersion are closely correlated with a high risk of ventricular arrhythmias and sudden death (Upegui \& Gómez, 2015; Ware \& Christensen, 1999).

Two animals in the present study presented isolated premature ventricular complexes (PVC), and one cat showed this arrhythmia 14 times in the tracing. We classified all PVC as unifocal, interpolar, focusing on right ventricle, some with the presence of the phenomenon $\mathrm{R}$ on $\mathrm{T}$ predisposes to ventricular tachycardia (Tilley \& Goodwin, 2002).

PVC is an abnormal heartbeat that occurs earlier than expected (Tilley \& Goodwin, 2002). There are numerous causes for this arrhythmia; however, in this study, we believe that its development was the result of starvation. Over time, the body begins to use muscle tissue as the main source of energy, leading to muscle damage and electrolyte disturbance. Electrolyte imbalance alters ventricular impulse formation, which may result in the formation of PVC, as seen in humans with anorexia (Gottdiener et al., 1978; Upegui \& Gómez, 2015).

With regard to the analysis of cardiac depolarization, we observed QRS prolongation in one third of the studied animals, as well as an increase in R-wave amplitude in two animals. This phenomenon may occur in ventricular overloads (Tilley \& Goodwin, 2002), but no animal showed signs of heart disease, and QRS prolongation is a common electrocardiographic alteration in humans with anorexia (Upegui \& Gómez, 2015).

In the analysis of ventricular repolarization, we observed an increase in $\mathrm{T}$ wave amplitude in $14.81 \%$ of the felines. T-wave alterations occur in both humans and cats and are observed in metabolic disorders (hypoglycemia, anemia, shock, fever, and hyperkalemia), myocardial hypoxia, drug intoxication, and neurological disease (Tilley \& Goodwin, 2002). In humans with anorexia, the $\mathrm{T}$ wave amplitude is reduced due to a decrease in myocardial muscle mass (Gottdiener et al., 1978; Upegui \& Gómez, 2015). However, in felines there is no minimum amplitude standard for this wave, and thus we did not perform this analysis.

The muscular consumption that occurs in malnourished felines is observed through the evaluation of the history, physical examination, increase in serum enzymes CK, AST, and lactate. 
The cardiac musculature is also affected and exhibits electrocardiographic abnormalities, such as in the duration of the QRS complex and increase in the QT interval.

Greater knowledge of laboratory and cardiovascular complications due to malnutrition empowers veterinarians to identify a problem early and reverse it. Anorexic felines can serve as a model to study the disease in humans.

\section{References}

Acierno, M. J., Johnsom, M. E., Eddleman, L. A., \& Mitchell, M. A. (2008). Measuring statistical agreement between four point of care (POC) lactate meters and a laboratory analyzer in cats. Journal of Feline Medicine and Surgery, 10(2), 110-114. doi: 10.1016/j.jfms.2007.07.002

Bagga, A., Tripathi, P., Jatana, V., Hari, P., Kapil, A., Srivastava, R. N., \& Bhan, M. K. (2003). Bacteriuria and urinary tract infections in malnourished children. Journal of Pediatric Nephrology, 18(4), 366-370. doi: 10.1007/s00467-003-1118-0

Bouquegneau, A., Dubois, B. E., Krzesinski, J. M., $\&$ Delanaye, P. (2012). Anorexia nervosa and the kidney. American Journal of Kidney Disease, 60(2), 299-307. doi: 10.1053/j.ajkd.2012.03.019

Fascetti, A. J., Mauldin, G. E., \& Mauldin, G. N. (1997). Correlation between serum creatine kinase activities and anorexia in cats. Journal of Veterinary Internal Medicine, 11(1), 9-13. doi: 10.1111/j.19391676.1997.tb00066.x

Franzoni, F., Mataloni, E., Femia, R., \& Galetta. F. (2002). Effect of oral potassium supplementation on QT dispersion in anorexia nervosa. Acta Paediatrica, 91(6), 653-656. doi: 10.1080/080352502760069052
Gottdiener, J. S., Howard, A. G., Henry, W. L., Borer, J. S., \& Ebert, M. H. (1978). Effects of selfinduced starvation on cardiac size and function in anorexia nervosa. Circulation, 58(3), 425-433. doi: 10.1161/01.cir.58.3.425

Kaneko, J. J., Harvey, J. W., \& Bruss, M. L (2008). Blood analyte reference values in small and some laboratory animals. In J. J. Kaneko, J. W. Harvey, \& M. L. Bruss (Eds.), Clinical biochemistry of domestic animals (6nd ed., pp. 889-895). Greenwood Village: Elsevier.

Kollai, M., Bonyhay, I., Jokkel, G., \& Szonyi, L. (1994). Cardiac vagal hyperactivity in adolescent anorexia nervosa. European Heart Journal, 15(8), 1113-1118. doi: 10.1093/oxfordjournals.eurheartj.a060636

Laflamme, D. P. (1997). Development and validation of a body score system for cats: a clinical tool. Feline Practice, 25(5/6), 13-18.

Thatcher, C. D., Hand, M. S., \& Remillard, R. L. (2010). Small animal clinical nutrition: an interactive process. In M. S. Hand, C. D. Thatcher, R. L. Remillard, P. Roudebush, \& B. J. Novotny (Eds.), Small Animal Clinical Nutrition (5nd ed., pp. 1-18). Topeka: Mark Morris Institute.

Tilley, L. P., \& Goodwin, J. K. (2002). Manual de cardiologia para cães e gatos (3nd ed.). São Paulo: Roca.

Upegui, C. V., \& Gómez, J. (2015). Alteraciones electrocardiográficas en anorexia nervosa: revisión crítica de la literatura. Revista Colombiana de Psiquiatría, 44(1), 33-40. doi: 10.1016/j. rcp.2014.09.006.

Ware, W. A., \& Christensen, W. F. (1999). Duration of the QT interval in healthy cats. American Journal of Veterinary Research, 60(11), 1426-1429.

Webb, C. B. (2018). Hepatic lipidosis: clinical review drawn from collective effort. Journal of Feline Medicine Surgery, 20(3), 217-227. doi: $0.1177 / 1098612 \times 18758591$ 
